Japan. J. Med. Sci. Biol., 28, 127-138, 1975

\title{
TITRATION OF TETANUS ANTITOXIN BY PASSIVE HEMAGGLUTINATION
}

\section{TITRATION OF GUINEA-PIG ANTITOXINS AT VARIOUS PERIODS OF IMMUNIZATION}

\author{
SHOICHI KAMEYAMA ANd SATORU KONDO \\ The 2nd Department of Bacteriology, National Institute of Health, \\ Kamiosaki, Shinagawa-ku, Tokyo 141, Japan
}

(Received: January 10, 1975)

\begin{abstract}
SUMMARY: An improved technique for passive hemagglutination (HA) for titration of tetanus antitoxin was described. The use of highly purified tetanus toxoid and of improved diluent increased the specificity and reproducibility of the test. Several hundreds of specimens of guinea-pig serum taken at various stages of immunization were titrated by HA and toxin neutralization (NT) in mice. The ratio of HA to NT titers varied significantly depending on the immunization stage; higher at early stages and lower at later stages. The high HA/NT ratio was not due to the IgM antitoxin, which is very rare in guinea pigs. The variation in discrepancy between HA and NT titers decreased considerably by grouping the serum specimens with respect to the stage of immunization. Thus, it is possible to predict the in vivo titer of a tetanus antitoxin accurately enough for clinical study. The HA test may be useful as an alternative method for titrating tetanus antitoxin in the field trials. Moreover, it can be used for the study of characteristics of antitoxins.
\end{abstract}

\section{INTRODUCTION}

Stavitsky $(1954 a, b)$ described methods for titration of diphtheria and tetanus antitoxins by passive hemagglutination (HA). However, disagreement between the titer of an antitoxin determined by $\mathrm{HA}$ and that by toxin neutralization in animals has often be reported (Scheibel, 1956; Fulthorpe, 1957, 1958; Scheibel et al., 1962; Hardegree et al., 1970; van Ramshorst, 1971; Byčenko et al., 1971). Such discrepancy hampered the routine use of the technique, though it is suitable for the clinical study and laboratory use when many serum specimens are to be examined. One of the factors responsible for the discrepancy may reside in the difference in the mechanisms of the two serological tests. However, contamination of the toxin with extraneous antigens may also contribute to the discrepancy, especially in the case of titration of tetanus antitoxin.

This paper describes a modification of the procedure of the HA test by using highly purified tetanus toxoid and application of the technique for the study of serological characteristics of tetanus antitoxins obtained at various stages of immunization.

亀山昭一・近藤 了（国立予防衛生研究所細菌第二部） 


\section{Materials ANd Methods}

Tetanus toxoid: Culture filtrate of Clostridium tetani grown in a peptone medium was obtained from Chiba Serum Institute. Tetanus toxin was precipitated with ammonium sulfate at $30-60 \%$ saturation. The precipitate was dissolved in and dialyzed against 0.02 м Tris-HCl buffer $(\mathrm{pH} \mathrm{7.5)}$ at $4 \mathrm{C}$. The toxin was further purified by chromatography on DEAE-cellulose equilibrated with the buffer. Elution was carried out by sodium chloride gradient $(0.05 \mathrm{M}-0.12 \mathrm{M})$ in the same buffer. The toxin fraction was applied to gel filtration on Sephadex G-100 after concentration with Ficoll (Pharmacia). The specific activity of the final product of the purified toxin was about $3,000 \mathrm{Lf} / \mathrm{mg} \mathrm{N}$. The purified toxin at a concentration of $200 \mathrm{Lf} / 0.1 \mathrm{ml}$ formed a single precipitation line when tested by double diffusion with the serum of a hyperimmunized horse. The purified toxin $(500 \mathrm{Lf} / \mathrm{ml})$ was detoxified with formalin at $0.1 \%$ and L-lysine at $0.05 \mathrm{M}$. In 3 days at room temperature the mixture was added again with $0.1 \%$ formalin and incubated at $37 \mathrm{C}$. Toxoiding was completed usually within a week. If toxicity still remained, another portion of formalin was added at $0.1 \%$. The mixture was kept at $\mathrm{pH} 7.0$ during the whole period for toxoiding. The toxoid was then dialyzed against $0.02 \mathrm{~m}$ Tris- $\mathrm{HCl}(\mathrm{pH} 7.5)$ and kept at $4 \mathrm{C}$ until use. It was used for sensitization of red cells and for immunization. For the latter purpose, plain and adsorbed (to aluminium hydroxide) toxoids were used.

Standard and Reference Tetanus Antitoxin for $H A$ : Standard Tetanus Antitoxin is distributed as a solution of $5 \mathrm{IU} / \mathrm{ml}$ in glycerin saline. Since the Standard was rather low in hemagglutinating activity (see below), a pool of commercial Human Anti-Tetanus Immunoglobulin was used as a reference for HA. The reference was lyophilized and standardized against the Standard by toxin neutralization in mice; one ampoule contained $190 \mathrm{IU}$ of tetanus antitoxin. Before use, this preparation was dissolved in saline containing $0.01 \%$ thimerosal to $1 \mathrm{IU} / \mathrm{ml}$; the solution was usable for one month if kept at $4 \mathrm{C}$.

Test specimens: Guinea-pig antitoxins were used in this study. Each guinea pig weighing $300-400 \mathrm{~g}$ was immunized with a dose of $30 \mathrm{Lf}$ of plain toxoid or $10 \mathrm{Lf}$ of adsorbed toxoid, and bled in 3, 5, 8, 14, 28 and 42 days. Each animal received a second dose of the tetanus toxoid 6 weeks after the primary immunization and was bled in 2 and 6 weeks. A pool of sera from guinea pigs hyperimmunized with seven doses of commercial adsorbed tetanus toxoid was also used. A pool of unimmunized guinea-pig sera was used as a negative control. All samples were kept at $-20 \mathrm{C}$ until use.

Preparation of sensitized sheep red cells: Sheep red cells were formalinized by the method described by Weinbach (1959) and modified by Tomizawa, Kasamatsu and Yamaya (1969). The formalinized sheep red cells (FSRC) were sensitized with the purified tetanus toxoid in the presence of bis-diazotized benzidine (BDB). The BDB solution was prepared according to the method described by Butler (1963). Benzidine was dissolved in $1 \% \mathrm{HCl}$ at $0.46 \mathrm{~g} / 100 \mathrm{ml}$; the solution was cooled to $0-2 \mathrm{C}$ in ice water. A solution of $\mathrm{NaNO}_{2}$ was freshly prepared 
by dissolving $0.35 \mathrm{~g}$ in $10 \mathrm{ml}$ of distilled water at $0-2 \mathrm{C}$. The $\mathrm{NaNO}_{2}$ solution was added dropwise to the benzidine solution with constant stirring (10 $\mathrm{ml}$ in $5 \mathrm{~min})$. The mixture was stirred continuously for $5 \mathrm{~min}$ and kept at cold for $30 \mathrm{~min}$ with stirring at every $5 \mathrm{~min}$ (BDB solution). FSRC in a $5-\mathrm{ml}$ portion of a $10 \%$ suspension were washed twice with saline and made to a $50 \%$ suspension with chilled $0.11 \mathrm{~m}$ phosphate buffer, $\mathrm{pH} 7.2$ (refered to as 7.2-buffer). The suspension was added with $30 \mathrm{ml}$ of tetanus toxoid $(10 \mathrm{Lf} / \mathrm{ml})$ in the same buffer. A freshly prepared $\mathrm{BDB}$ solution was diluted to $1: 15$ with chilled 7.2-buffer and $15 \mathrm{ml}$ of the diluted $\mathrm{BDB}$ was added to $31 \mathrm{ml}$ of the toxoid-cell mixture. The mixture was kept at room temperature for $10 \mathrm{~min}$ and centrifuged at 2,000 rpm for about 5 min. The packed cells were washed twice in $40 \mathrm{ml}$ of the serum diluent (see below) and resuspended in $25 \mathrm{ml}$ of the diluent to yield a $2 \%$ suspension of sensitized FSRC.

Serum diluent: The following solution was used to suspend the sensitized cells and to dilute serum specimens.

Sodium chloride solution $(0.15 \mathrm{M})$

$\mathrm{MgSO}_{4} \cdot 7 \mathrm{H}_{2} \mathrm{O}$

$490 \mathrm{ml}$

Normal rabbit serum (inactivated or absorbed or both, if necessary) $5 \mathrm{ml}$

Thimerosal solution (1\%)

$5 \mathrm{ml}$

Addition of magnesium made the end point determination easier. Normal rabbit serum (NRS) had to be tested preliminarily to see if absorption with or without inactivation and absorption was necessary (see below).

Hemagglutination test: Two methods were used; the tray method and the automated micro titration method (AMTM). In the former, trays each with $8 \times 10$ wells were used (Tominaga Works Ltd., Tokyo). Each well was $15 \mathrm{~mm}$ in diameter and $10 \mathrm{~mm}$ in depth. All test specimens were diluted to 1:5 with saline, inactivated at $56 \mathrm{C}$ for $30 \mathrm{~min}$, and absorbed with $0.1 \mathrm{ml}$ of unsensitized FSRC per $2 \mathrm{ml}$ of a serum dilution. Serial twofold dilutions of test specimens, the reference antitoxin and NRS were prepared in volumes of $0.3 \mathrm{ml}$ and each was added with $0.03 \mathrm{ml}$ of the sensitized FSRC suspension. The tray was then shaken gently and kept overnight at room temperature. Agglutination was read according to Butler (1963) and ++ was taken as the end point. Hemagglutination units (HAU/ml) were calculated relatively to the reference antitoxin and mean values were taken from at least three determinations; five or more determinations were carried out when considerable divergencies in the titers were observed.

The AMTM was carried out with a 96 channel automatic pipetter (Model 222-1A)*, an automatic diluter (Model 222-20PU)* and microtiter plates (type U)*. In this method, the sensitized FSRC suspension was diluted to 1:30. Serum specimens were inactivated and absorbed as before. Serial twofold dilutions of each specimen were prepared in volumes of $0.025 \mathrm{ml}$ and each was added with $0.075 \mathrm{ml}$ of the diluted FSRC suspension. The other procedures were similar to those of the tray method.

Toxin neutralization test: Toxin neutralization in mice (NT) was carried

\footnotetext{
* Cooke Engineering Company
} 
out at a $\mathrm{L}+/ 1,000$ level in gpc/S mice each weighing $15-17 \mathrm{~g}$. The diluent was $0.017 \mathrm{M}$ phosphate buffered saline $(\mathrm{pH} 7.0)$ containing $0.2 \%$ gelatin. At least three dilutions at $0.5 \mathrm{log}$ intervals were used and two mice were allotted for each dilution. The confidence interval of the potency was about $30 \%$.

The antitoxin titers were calculated by the score method (Kubota et al., 1962) with some modifications and expressed in international units (IU/ml). For calculation, symptoms and death times of the mice inoculated with toxin-antitoxin mixtures were transformed into the following scores:

\section{Symptom}

Death within $45 \mathrm{hr}$

Death between $46-51 \mathrm{hr}$

Score

Death between $52-64 \mathrm{hr}$

Death between $65-86 \mathrm{hr}$

Death between $87-105 \mathrm{hr}$

Death between 106-133 hr

Death in $134 \mathrm{hr}$ or later, or survival with severe symptom

\section{Results}

\section{Examinations of NRS to be Added to the Diluent}

NRS is commonly included in the diluent for HA after inactivation and adsorption with unsensitized sheep red cells (Stavitsky, 1954a, Stavitsky and Arquilla, 1955). At an early stage of this study, however, nonspecific agglutination was frequently observed when the conventional diluent (saline containing pretreated NRS) was used. Actually 18 of 32 pretreated NRS specimens $(56 \%)$ were not usable. Addition of magnesium $\left(0.2 \% \mathrm{MgSO}_{4} \cdot 7 \mathrm{H}_{2} \mathrm{O}\right)$ reduced nonspecific agglutination and made reading the end point easier. With some specimens of NRS, inactivation had rather an adverse effect. It is, therefore, necessary to run a preliminary test to determine which method is suitable for the pretreat-

TABLE I

Comparison of tetanus antitoxin titers obtained by the tray method and by AMTM

\begin{tabular}{ccc}
\hline \multirow{2}{*}{ Atitoxin $^{1)}$} & \multicolumn{2}{c}{ Titers $(\mathrm{HAU} / \mathrm{ml})$} \\
\cline { 2 - 3 } & Tray method & AMTM \\
\hline \multirow{3}{*}{ After the primary injection } & 2.0 & 2.2 \\
& 2.0 & 2.4 \\
& 10 & 3.4 \\
\hline \multirow{2}{*}{ After the secondary injection } & 37 & 27 \\
& 40 & 44 \\
& 40 & 38 \\
& 37 & 35 \\
\hline
\end{tabular}

1): Guinea-pig antitoxins. 
ment of NRS. By such procedures, $97 \%$ of NRS became available for the test.

\section{Comparison between Tray Method and AMTM}

Two methods (tray and AMTM) were compared with eight specimens. The sensitivity of the tray method was consistently higher by twofold to 4-fold, but the titers in $\mathrm{HAU} / \mathrm{ml}$ determined by the two methods were similar to each other as shown in Table I. Most of the following data were obtained by AMTM.

\section{Titration of Guinea-pig Tetanus Antitoxin at Various Stages of Immunization}

No antitoxin activity was detected by the HA test, being below $0.001 \mathrm{HAU} /$ $\mathrm{ml}$, in sera taken in 3,5 or 8 days after the primary injection with either plain $(30 \mathrm{Lf})$ or adsorbed $(10 \mathrm{Lf})$ toxoid. Antitoxin $(0.01-0.26 \mathrm{HAU} / \mathrm{ml})$ was detected in all serum specimens taken in 2 weeks and the titers increased rapidly until the 6 th week as shown in Fig. 1. Sixteen of 40 specimens taken at the 2 weeks'

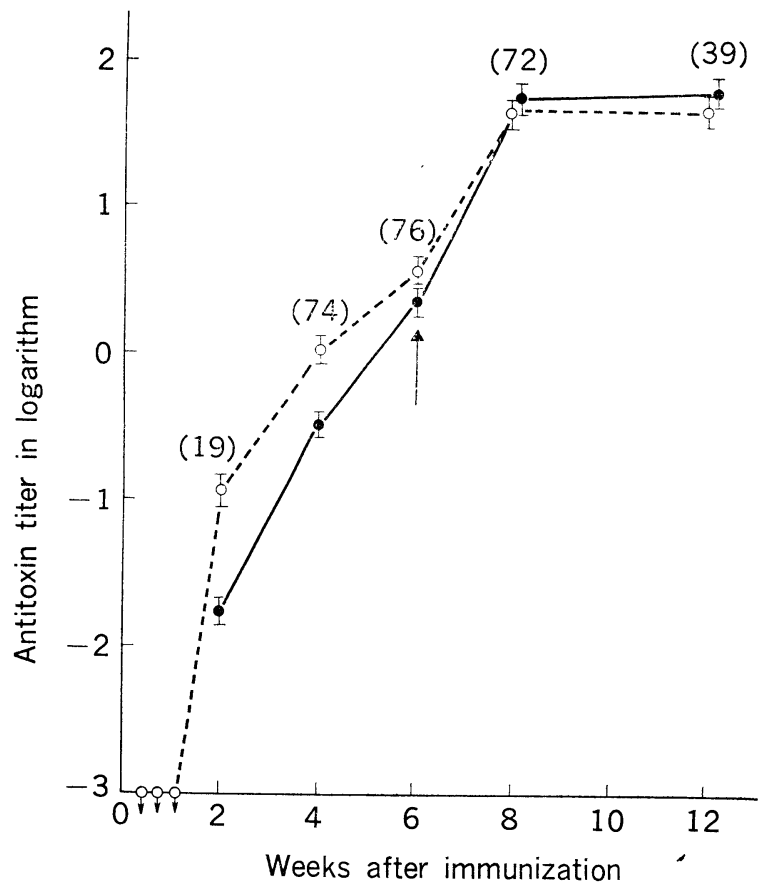

Fig. 1. Production of tetanus antitoxin in guinea-pigs as determined by HA and NT ○...- $\mathrm{HAU} / \mathrm{ml}$, determined by $\mathrm{HA}$.

- IU $/ \mathrm{ml}$, determined by the mouse method.

9 The symbol shows that the titer was below the detectable level.

The arrow indicates the 2nd immunization.

Figures in parentheses indicate number of samples examined. Bars above and below each point are the $95 \%$ confidence interval. Few specimens showing outlying HAU/IU ratios were omitted from the figure by Grubbs' outlyier test. 


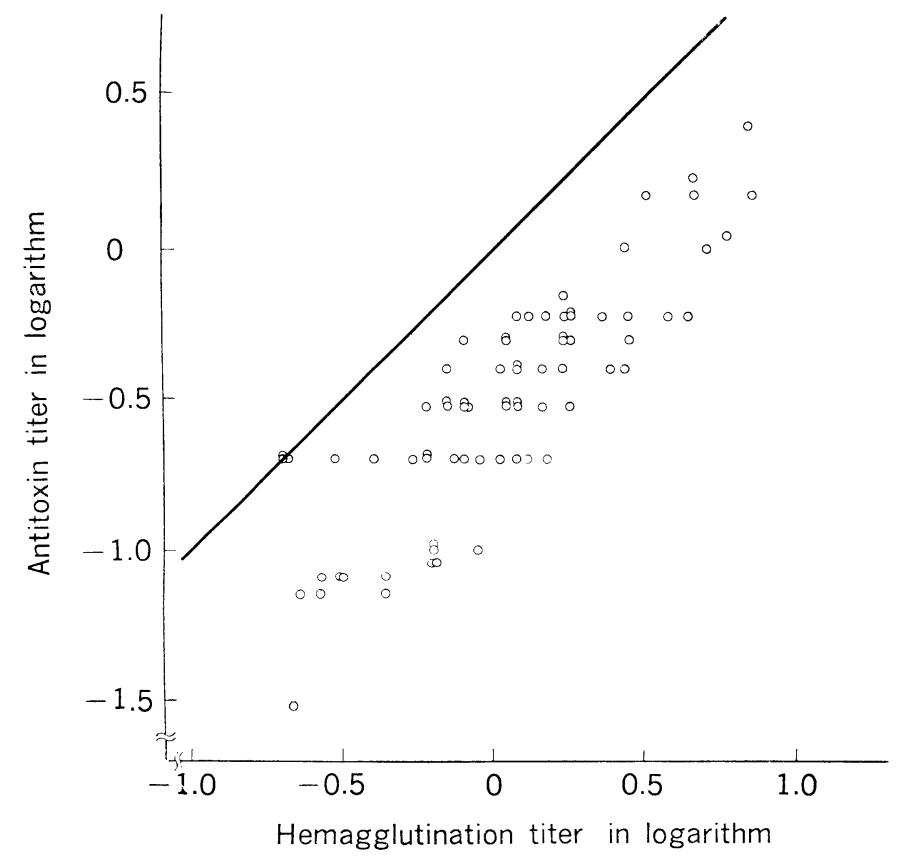

Fig. 2. Relationship between HA and NT titers of tetanus antitoxins (Guinea-pig sera, 4 weeks after primary injection)

The solid line shows the hypothetical line of unity of the two values (the same as Figs. 3 and 4).

bleeding showed $0.1 \mathrm{HAU} / \mathrm{ml}$ or higher titers; the others showed below the detectable level. Twenty specimens with titers higher than $0.03 \mathrm{HAU} / \mathrm{ml}$ were titrated by NT. The results are shown in Fig. 1, except for a specimen showing an outlying $\mathrm{HAU} / \mathrm{IU}$ ratio. Nineteen specimens having $\mathrm{HA}$ titers of $0.03-1.3 \mathrm{HAU} / \mathrm{ml}$ showed NT titers of $0.01-0.03 \mathrm{IU} / \mathrm{ml}$, the HAU titers being significantly higher than the in vivo titers. The ratio HAU/IU ranged 3-18 with a geometric mean of 6.76 , except for the specimen showing a value of 65 .

The ratio $\mathrm{HAU} / \mathrm{IU}$ decreased gradually at later stages of immunization. Results of titration of 74 sera taken at the 4 weeks' bleeding are illustrated in Fig. 2, in which in vivo titers (IU) are plotted against HA titers (HAU). Almost all points (71 of 74) were found below the line showing unity. The ratio of $\mathrm{HAU} / \mathrm{IU}$ ranged from 1.0 to 7.5 with a geometric mean of 3.34, except for four specimens showing values of 10-19. As shown in Fig. 3, the HAU/IU ratios after 6 weeks were close to the unity ranging from 0.55 to 5.4 with a mean of 1.62 , except for a specimen with a ratio of 7.0.

Figure 4 summarizes the results on the serum specimens taken after the secondary immunization. The in vivo titers were equal to or slightly lower than the HA titers (mean ratio: 0.78), in sharp contrast to the sera taken after the primary immunization. The tendency was the same with sera taken 6 weeks after 




Fig. 3. Relationship between HA and NT titers of tetanus antitoxins (Guinea-pig sera, 6 weeks after primary injection)

the booster injection (mean ratio: 0.74). Although varied from one experiment to another, the HAU/IU ratio was large at an early stage of immunization and decreased as the immunization proceeded.

Statistical analyses of all the data gave a straight-line relationship between HA and NT titers, as shown in Fig. 5, by grouping the sera according to the immunization stage. Calculated coefficients of correlation were close to one another ranging from 0.836 to 0.913 , but the position of the line differed depending on the immunization stage as did the HAU/IU ratio. An approximate in vivo titer can be estimated from the formula shown in Fig. 5, if the immunization stage is considered.

\section{Molecular Sieving of Sera with High HAU/IU Ratios}

Some serum specimens with relatively high HA titers taken at early stages of immunization were pooled and it was subjected to fractionation on Sephadex G-200 (Fig. 6). Each fraction was assayed by HA with and without treatment with 2-mercaptoethanol (2-Me). Two peaks of HA activity were obtained at the positions corresponding to $\operatorname{IgM}$ and $\operatorname{IgG}$; with other specimens, the first peak was sometimes lower than that in Fig. 6. The HA activity of the IgM fraction was consistently lower than $5 \%$ of the total activity (IgM+IgG). The HA activities of the fractions corresponding to IgM decreased slightly when treated with 2-Me, while those of the other peak were not affected. 


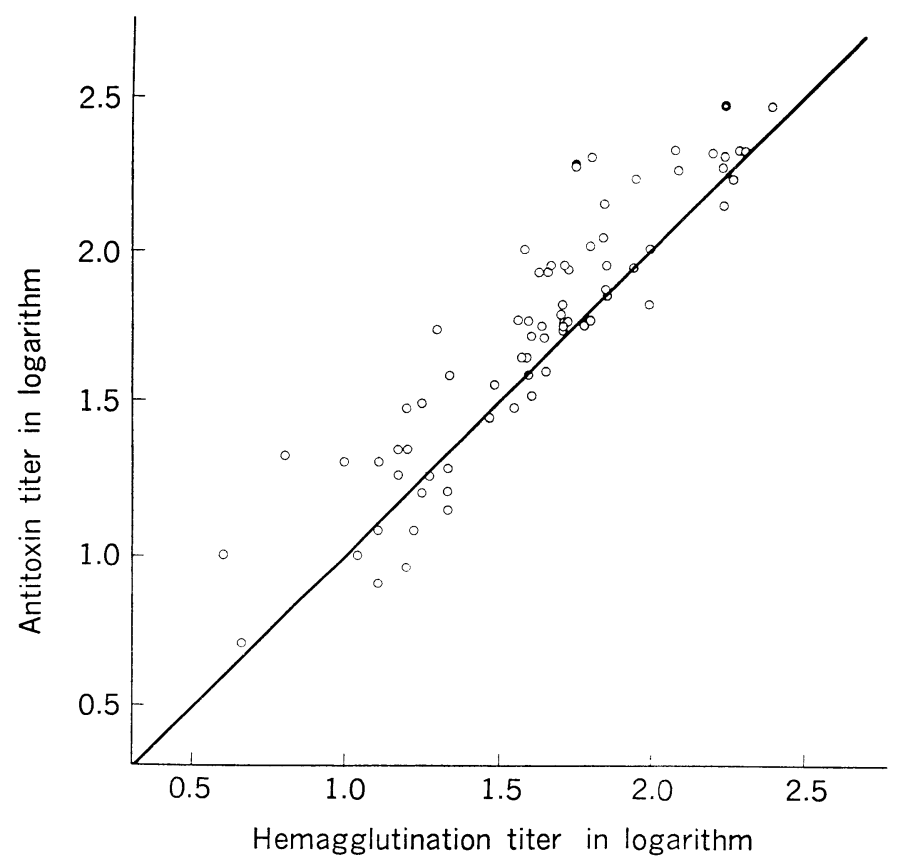

Fig. 4. Relationship between HA and NT titers of tetanus antitoxins (Guinea-pig sera, 2 weeks after secondary injection)

\section{Discussion}

Several different factors may be responsible for the discrepancies between HA and NT titers of tetanus antitoxin. They are (1) extraneous antigenic substances, (2) difficulty in the reading of the end points of hemagglutination tests, (3) experimental error inherent to the animal tests, and (4) difference in the serological characteristics of antitoxins.

Although we paid little attention to the first factor, a highly purified toxoid may be preferable to minimize possible non-specific reactions due to some extraneous antigens.

A slight modification of the method described in this paper made the end points clearer. Since both the tray method and AMTM use small amounts of specimens, several repeated determinations are necessary to minimize the error inherent to such micro-methods. Five or more assays are needed, if possible. The score method of the in vivo test may increase the accuracy and precision of NT. With such considerations on the techniques, the discrepancies between two titers were reduced considerably.

As regards the fourth factor, Scheibel (1956) pointed out the importance of the avidity of the sera. Raynaud (1967) also stated that the specimens of diphtheria antitoxin with different avidities showed different attitudes in HA. No such report has been published on tetanus antitoxin. As shown in Figs. 2-4, the HAU/ 




Fig. 5. Correlation between HA and NT titers of guinea-pig tetanus antitoxin $\cdots \cdots . \cdots \cdots, 4$ weeks after primary injection.

- 6 weeks after primary injection.

- -2 weeks after secondary injection.

- - - 6 weeks after secondary injection.

$\mathrm{X}: \mathrm{HAU} / \mathrm{ml}, \quad \mathrm{Y}: \mathrm{IU} / \mathrm{ml}$.

IU ratio was considerably different depending on the stage of immunization. However, if data were analyzed with respect to every immunization stage, a high correlation was observed between HA and NT titers within a range of variation attributable to experimental errors. If the immunization stage is known, the in vivo titer of a serum specimen can be calculated from the HA titer.

It was interesting to see whether the relatively high HA titer at an early stage of immunization was related to the specific IgM content of the test serum, since IgM showed a higher HAU/NT titer ratio with other antitoxins. Sakaguchi and Sakaguchi (1973) described that IgM with a relatively higher HA titer was produced at an early stage (9 days) of immunization of rabbits with botulinum toxoid. Robbins (1965) also found that IgM with a relatively high HA titer was detected in men 12 days after immunization with diphtheria toxoid and that sera obtained after multiple injections contained mainly IgM antitoxin.

Figure 6 suggests the presence of IgM in some pooled sera. However, it 


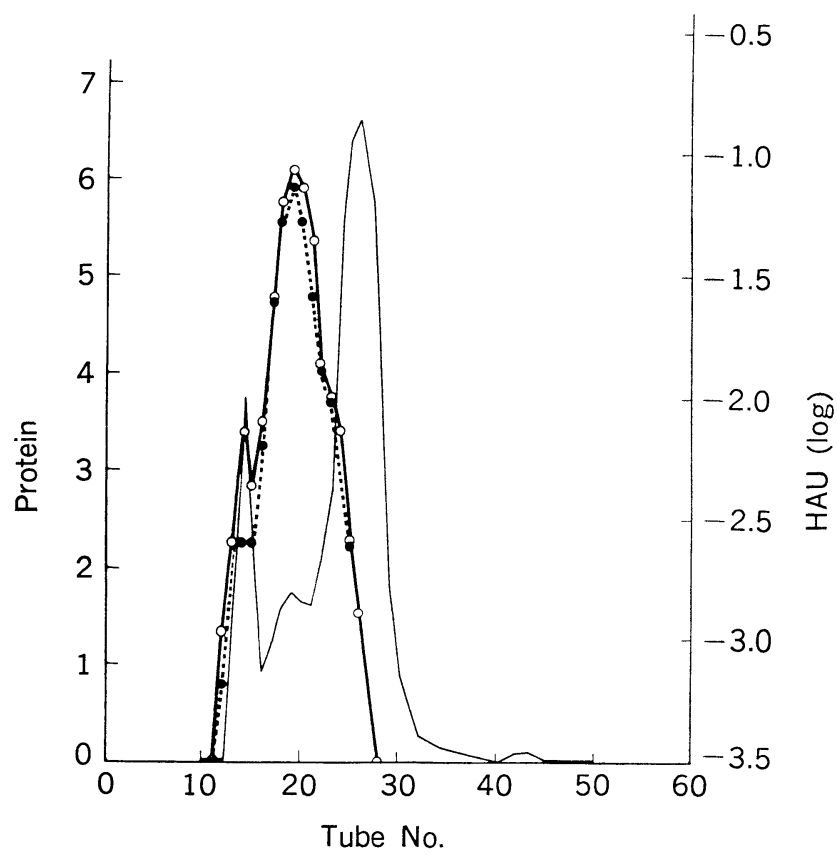

Fig. 6. Gel filtration on a Sephadex G-200 column of pooled guinea-pig serum One and half $\mathrm{ml}$ of serum was placed on a column $(1.5 \times 45 \mathrm{~cm})$ of Sephadex G-200 equilibrated with $0.02 \mathrm{M}$ Tris-HCl buffer $(\mathrm{pH} 7.5)$. Elution was carried out with the same buffer and 2-ml fractions were collected.

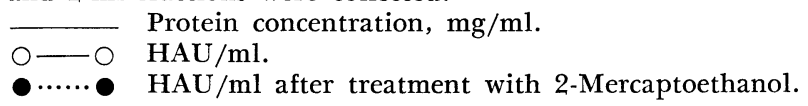

never represented the main component of guinea-pig antitoxin at an early stage of immunization, because no antitoxin was detected before the 8th day of immunization and many samples taken in $2-4$ weeks after the primary immunization contained no detectable $\mathrm{HA}$ activity in the IgM fraction. The 2-Me resistance of the fraction eluted at the position corresponding to that of IgM (Fig. 6) may also support the above conclusion. Even if the fraction corresponding to IgM contained some HA activity (Fig. 6), it can not explain the high HAU/IU ratio of the original unfractionated serum, because the activity of the fraction was always lower than $5 \%$ of the total activity. The change in the ratio seem to be related rather to the different characteristics of IgG antitoxin. Avidity may be important as described by Scheibel (1956) and Raynaud (1967). Further study is being made on this point in this laboratory.

Another experiment with human antitoxin showed a tendency similar to the above with regard to the relationship between the HAU/IU ratio and the immunization period; the value were high at 4 weeks after the basic immunization and became lower later. Further experiments are needed to find whether IgM contributes to the high $\mathrm{HAU} / \mathrm{IU}$ ratio in human sera. In this respect, we have 
recently observed that production of tetanus antitoxin of IgM nature differs depending on the species of the experimental animal (to be published).

The extent of variation of discrepancies between HA and NT titers can be reduced significantly by taking the immunization period into account and estimation of the in vivo titer accurately enough for clinical use can be made from the HA titer.

\section{Acknowledgment}

The authors wish to thank Dr. R. Murata, Head of the 2nd Department of Bacteriology, National Institute of Health, Tokyo, for his helpful advice and encouragement in performing the present investigation.

\section{REFERENCES}

Butler, W. T. (1963): Hemagglutination studies with formalinized erythrocytes. Effect of BisDiazo-Benzidine and tannic acid treatment on sensitization by soluble antigen. J. Immunol., 90, 663-671.

Byčenko, B., Grin, E., Matveev, K. I., Cvjetanović, B., Vorst, E. A. and Stroganove, M. (1971): The level of tetanus immunity in the population of villages in Bosnia and Herzegovina. Bull. W.H.O., 45, 431-443.

Fulthorpe, A. J.(1957): Tetanus antitoxin titration by haemagglutination. J. Hyg., 55, 382-401. Fulthorpe, A. J. (1958): Tetanus antitoxin titration by haemagglutination at a low level of test. J. Hyg., 56, 183-189.

GrubBs, F. E. (1950): Sample criteria for testing outlying observation. Ann. Math. Statist., 21, 27-58.

Hardegree, M. C., Barile, M. F., Pittman, M., Maloney, C. J., Schofield, R. And MacLennan, R. (1970): Immunization against neonatal tetanus in New Guinea. 4. Comparison of tetanus antitoxin titers obtained by haemagglutination and toxin neutralization in mice. Bull. W.H.O., 43, 461-468.

Kubota, K., Wada, E., Yamamoto, A. and Murata, R. (1962): Studies on the combined vaccine (pertussis-diphtheria-tetanus). II. On the antigenicity of tetanus toxoid. Japan. J. Microbiol., 17, 184-188 (text in Japanese).

Raynaud, M. (1967): Heterogeneity of diphtheria antibodies. p. 197-251. In B. Cinader [ed.], Antibodies to Biologically Active Molecules. Pergamon Press, London.

Robbins, J. B. (1956): Studies on the interaction of immunoglobulins toward protein antigens with biological activity. Czech. Sc. Sci., 241-251.

Sakaguchi, G. AND SAKaguchi, S. (1973): Development of antibody to each component of Clostridium botulinum type E progenitor toxin. Japan. J. Med. Sci. Biol., 26, 187-195.

Scheibel, I. (1956): A comparative study on intracutaneous and haemagglutination procedures for assaying diphtheria antitoxin, with special reference to the avidity of the antitoxin. Acta Path. Microbiol. Scand., 39, 455-468.

Scheibel, I., Bentzon, M. W., Tulinius, S. ANd Bojlen, K. (1962): Duration of immunity to diphtheria and tetanus after active immunization. With mention of non-conformity between haemagglutination and neutralizing diphtheria antitoxin titres in some human sera. Acta Path. Microbiol. Scand., 55, 483-495.

Stavitsky, A. B. (1954a): Micromethods for the study of proteins and antibodies. I. Procedure and general applications of hemagglutination and hemagglutination-inhibition reactions with tannic acid and protein-treated red blood cells. J. Immunol., 72, 360-367.

Stavitsky, A. B. (1954b): Micromethods for the study of proteins and antibodies. II. Specific applications of hemagglutination and hemagglutination-inhibition reactions with tannic acid and protein-treated red blood cells. J. Immunol., 72, 368-375.

Stavitsky, A. B. And Arquilla, E. R. (1955): Micromethods for the study of proteins and antibodies. III. Procedure and applications of hemagglutination and hemagglutination-inhibition reactions with Bis-Diazotized Benzidine and protein conjugated red blood cells. J. Immunol., 74, 306-312. 
Tomizawa, T., Kasamatsu, S. And Yamaya, S. (1969): Usefulness of the hemagglutination test using Treponema pallidum antigen (TPHA) for the serodiagnosis of syphilis. Japan. J. Med. Sci. Biol., 22, 341-350.

van RAmshorst, J. D. (1971): Titration of diphtheria and tetanus antitoxins in sera of low titer. Bull. W.H.O., 45, 213-218.

von WeINBACH, R. (1959): Die verwendbarkeit formolbehandelter erythrozyten als antigenträger in der indirekten haemagglutination. II. Schweiz. Z. Allg. Pathol., 22, 1-11.

YAMAmoto, A., Kondo, S. AND MURATA, R. (1970): Variation of Lf value of tetanus toxin depending on the reference antitoxins for flocculation. Japan. J. Med. Sci. Biol., 23, 117-121. 